The Disparity between Cultures on Going Back Home in The Dilemma of a Ghost

by

Ama Ata Aidoo

A Paper

Submitted by

Howayda Hassan Ali EI Sherif

To

The Literary Periodical of the Faculty of Arts, Science and Education Ain Shams University

Under the supervision of

Dr. Mona Anwar Wahsh

Kelesh

Associate Professor of English Literature

Literature

Faculty of Women

Women

Ain Shams University
Dr. Shahira Fikry

Lecturer of English

Faculty of

Ain Shams University 


\section{Abstract \\ The Disparity between Cultures on Going Back Home in The Dilemma of a Ghost by Ama Ata Aidoo}

The paper discusses the collision which occurs when African Americans return to Africa. Such collision reveals the racial and cultural estrangement between African Americans and Africans as a result of slavery and colonialism. This idea is traced through Aidoo's The Dilemma of a Ghost (1965) which portrays an African American woman, Eulalie Rush who marries the Ghanaian Ato Yawson and agrees to return with him to Ghana. Rather than being welcomed by her African brothers, Eulalie finds herself racially and culturally rejected for being the descendant of slaves and an American respectively. Being in this odd situation, she starts to apply the same American racist perspective regarding Africans. Eulalie's dilemma therefore represents African Americans in general and the continuous collision between their African roots and the African American acquired perspectives.

African Americans and Africans share the same racial roots which were the main reason behind their oppression either through slavery or colonialism. Both suffered from the same black curse that affected them physically and psychologically. But the longer they were separated, the more they were estranged from each other. Through time, the members of each group began to develop their own racial consciousness which was crystallized according to the cultural and social context they were placed in. Despite some attempts of reunion, unmistakable elements of division were there. This was clear in their different cultural practices, traditions, customs, and mostly in their sense of belonging, all of which the mutual skin color could not resolve.

The Dilemma of a Ghost (1965) by Ama Ata Aidoo (1942- ) exposes the encounter between Africans and African Americans who belong to the same origin. These cultural encounters reveal how African Americans in Africa were viewed by Africans as intruders whether as inferior slaves or superior 
colonizers. As a result of this African suspicion, African Americans underestimate their African brothers in spite of their common origin. This idea is reflected through the experience of the African American Eulalie Rush who decides to marry an African man, Ato Yawson and lives with him in Ghana.

As for the theoretical framework of the paper, it is based on the postcolonial theory focusing on the works of Frantz Fanon (1925-1961) as one of its major representatives. In his books Black Skin, White Masks (1952) and The Wretched of the Earth (1968), Fanon explains the psychological suffering of black people who underestimate themselves as a result of the white man's humiliation and eradication to their culture and sense of belonging. Also in Toward the African Revolution (1988), Fanon discusses the possibility of a collision between members of the same African race as a consequence to this cultural sabotage.

Both slavery and colonialism shared their devastating influences over the Africans' culture and personality. These influences were similar to what Fanon called in his book The Wretched of the Earth, "cultural estrangement" (210). It occurs because:

Every effort is made to bring the colonized person to admit the inferiority of his culture which has been transformed into instinctive patterns of behavior, to recognize the unreality of his "nation," and, in the last extreme, the confused and imperfect character of his own biological structure (Wretched 236).

This act of cultural pollution begins when the colonizer, and in the African American case the American enslaver, starts to impose his own culture as a much more superior and legitimate one. This turns the colonized people into distorted replicas of their colonizers, as they would be neither able to acquire this new forced culture completely nor return to their original one. Thus, the white man converted the culture of the black man into a weapon against him. This was achieved by presenting the white people's culture as superior and elevated, in contrast to the savage and inhuman African culture. These allegations transformed the African culture into a shameful burden that most blacks felt they must obliterate to be worthy of the white culture. This odd situation turned the enslaved Africans in America and the colonized Africans in Africa into deformed personalities. They became prisoners of an identity that was imposed on 
them by the white man. Unable to direct their anger towards their jailer, they turned this anger towards themselves and their brothers in race.

In Toward the African Revolution (1988), Fanon detected such cases in which "the enemy of the Negro is often not the white man but a man of his own color" (17). He explained that this phenomenon was a direct result to the white culture which many Africans had to adopt as a result of slavery and colonialism. When these white cultured blacks came face to face with other Africans of native culture and traditions, a clash occurred between the African brothers.

Fanon applied this possibility to the relation between "West Indians and Africans" (17). This model can be considered typical to the relation between African Americans and Africans. Though they looked alike as blacks, there remained one truth that "[t]he African was a Negro and the West Indian a European" (20). The situation was the same for the African Americans who were forced to adopt the American culture and to demean their own blackness. In this racial environment, the black man plead for whites saying," 'Don't pay attention to my black skin, it's the sun that has burned me, my soul is as white as yours' " (25).

Fanon then revealed that with the dawn of the African independence as well as the continuous rejection of whites to regard blacks as equal, many of the West Indians, and in this case the African Americans, directed their attention towards Africa. They began to look up to Africa and even to return to it "with their hearts full of hope, eager to rediscover the source, to suckle at the authentic breasts of the African earth" (25). Unfortunately, African Americans or in Fanon's terminology, West Indians who were optimistic about their new African life and culture were met by nothing but refusal. This African rejection had the most devastating effect on the African American who began to feel "[h]aunted by impurity, overwhelmed by sin, riddled with guilt, he was prey to the tragedy of being neither white nor Negro" (26).

This sense of bewilderment is typical of the African American who is seen as having two contrasting sides of his character. The first is the African side which resembles his racial origins and roots which he can never omit. The second however, is the American side which was imposed on him, but ironically he knows nothing except it. These contradicting sides are in a 
continuous state of war inside the African American person and the outcome of this war determines his character. When the American side wins exclusively, the person is considered a traitor to his own race and turns into a fake copy of white America. On the other hand, when the African side wins alone, the person becomes a traitor to his own American self which he was raised on for years. This situation is described by Du Bois through the concept of "double- consciousness":

One ever feels his twoness, an American, a Negro; two souls, two thoughts, two unreconciled strivings; two warring ideals in one dark body, whose dogged strength alone keeps it from being torn asunder (5).

After there long separation from each other, the acquiring of independence by several African governments ignited the African Americans' attention to their roots. Actually, Ghana initiated this liberation in 1957. As a result, many African Americans started to translate their honor in Africa by embracing the African culture. There were increasing indications "of re-Africanization" including "black-is-beautiful styles like Afro hairdos, African and Muslim names, and African clothing" (Conniff and Davis 304). For the first time they had a sense of belonging to their long lost culture and community. This of- course was in contrast to their previous attitude when African Americans tried to look as American as possible attempting though unsuccessfully to blend in.

The objective of this paper is to discuss the return of African Americans to Ghana and the reaction of both sides to this attempt as portrayed in Ama Ata Aidoo's play The Dilemma of a Ghost (1965).

Through The Dilemma of a Ghost, Aidoo portraysa violent example of how members of the same race regard each other with contempt. This is done through the marriage of the African Ato Yawson and the African American Eulalie Rush. This marriage reflects the playwright's interest in discussing the perspectives of both sides about each other. This is clear in Aidoo's words to Adeola James that "[u]ntil we have actually sorted out this whole question of African people, both on the continent and in the diaspora, we may be joking, simply going round in circles" (21). 
Instead of going through the usual racial clash between whites and blacks, Aidoo presents it between Ato's family and Eulalie. According to Ato's family, Eulalie who is now married to their son represents two of the worst evils. She is first a reminder of slavery and therefore she becomes despised and rejected for her impure lineage. Second, she represents colonialism through her foreign attitudes and behavior which are associated with white culture. This rejection that Eulalie feels causes her to revolt against the restrictions of the Ghanaian society.

Ato introduces Eulalie to his family as a woman who is "as black as we all are", but "has no tribe" $(17 ; 1)$ and knows nothing about her roots. Such painful truth contradicts with the value that the Africans give to their lineage and is clear in the words of $\mathrm{Nana}^{\mathbf{1}}$, the grandmother:

[...] The story you are telling us is too sweet, my grand-child. Since I was born, I have not heard of a human being born out of the womb of a woman who has no tribe. Are there trees which never have any roots? $(17 ; 1)$

Nana's ignorance of such a case is Aidoo's criticism to the Africans' deliberate oblivion to their role in the Atlantic slave trade. Though they played a central role in selling millions of Africans to the white man, they chose to forget that most of their brothers are now living the diaspora in Europe and America.

When Ato informs his family about Eulalie's origins as an African American, the entire family criticizes his choice. However, it is Nana's objection which is the strongest. The first thing that occurs to Nana is how she will face her ancestors 2 after her death. She believes that they would blame her for accepting the contamination of their lineage with the blood of a slave. This reflects the more negative, but realistic look that Africans have about African Americans:

My spirit Mother ought to have come for me earlier. Now what shall I tell them who are gone? The daughter of slaves who come from the white man's land. [...] 
Someone should lend me a tongue

Light enough with which to tell

My Royal Dead

That one of their stock

Has gone away and brought to their sacred precincts

The wayfarer! $(19 ; 1)$.

Before meeting Eulalie, Ato's family and society announce their rejection to her on the bases of being the descendent of slaves. The situation changes after they get to meet Eulalie and observe her way of life. At that time, Eulalie is no longer regarded as a slave, but rather as a white colonizer. They begin to see how much she is different from them and therefore she becomes rejected on the bases of being culturally white. A very important aspect that strengthens Eulalie's image as a colonizer and which sets a barrier between her and her African surrounding is that of language. Eulalie can onlyspeak the English language of Ghana's former colonizers. As for Ato's family, they are simple illiterate people who can only speak their native language.

With her foreign language and attitudes, Eulalie becomes the shocking contradiction to all what an African woman should be like. She adopts a modern way of life which contradicts with the rural simplicity of the village. As an educated city girl, Eulalie cannot imagine doing the house work by her own hands; therefore she uses "machines" $(38 ; 4)$ that are strange to the village's women. According to the second woman:

[...] Her water must be colder than hailstone.

I heard it said in the market place

Monka's teeth were set on edge

For drinking water in her house.

And her food never knows wood fire $(38 ; 4)$.

Though this might be ordinary in America, Eulalie's dependency on machines rather than her own effort is seen by Ghanaian women as something demeaning that decreases her value in life as a woman. Eulalie also becomes a sort of disgrace as she smokes, drinks in public and does not even seek the love of Ato's family. According to Ato's sister Monka, Eulalie 
is not by any means a woman since she does not act like the rest of the Ghanaian women in the village:

She reminds me of the words in the song:

'She is strange,

She is unusual.

She would have done murder

Had she been a man.

But to prevent

Such an outrage

They made her a woman!'

Look at a female! $(33 ; 3)$.

Such attitude shows how Africans suspect blacks who were raised up abroad. This feeling drives them to deny the fact that the members of the African diaspora come "from the same ethnic tree, the same African origin" (Jackson and Cothran 597).

In contrast with this harsh African reception, Aidoo's Eulalie Rush represents the sentimental vision that most of the Afro-Americans had about being easily welcomed and accepted by Africans. Aidoo however does not stop at this point, as she marks the developments in Eulalie's character when faced by the reality of the African rejection. Eulalie takes her journey back hoping to link herself to her roots, but soon she discovers how she is racially and culturally rejected by Africans. This shock of rejection re-activates her American side and she begins to treat the Africans from the same stereotypical and racist views of a white American. Unable to identify with either side, she finally turns to a ghost that does not belong to any identity.

Eulalie is portrayed by Aidoo as an African American young woman who was born and brought up having no cultural background except that of America. This situation continues until she meets Ato and falls in love with him. Her decision to marry him and to move to Ghana becomes her

expression for a deep sense of belonging. She appears highly optimistic and excited about going to Africa with Ato. As a young woman who has succeeded in her life and education, Eulalie feels that she has reached her 
utmost goals in life. She confesses to Ato that "I'm optimistic, Native Boy. To belong to somewhere again ... Sure, this must be bliss" (9; Prelude).

It is interesting to note how Eulalie addresses Ato as "Native Boy". It is this advantage that encourages Eulalie to marry him. She feels that this marriage will set her free from the chains of the American racism that has long violated her dignity as a human being. Based on this idea, Eulalie begins to narrate her fantasies about Africa and the places she is going to visit with Ato. She becomes excited when thinking about "[t]he palm trees, the azure sea, the sun and golden beaches ..." (9; Prelude). The way she describes Africa is filled with exaggerated romanticism that can be only found as Ato remarks in "a tourist brochure"(9; Prelude).

What heighten her sense of optimism are her feelings of affinity with Africans. To her, they are people who share her colour as well as her suffering that was caused by the white man. She conceptualizes that Ato's family can never mean her any harm or ridicule and therefore she is ready to accept them as her family. This lure that Africa represents for the Africans abroad is expressed by Fanon:

From the opposite end of the white world a magical Negro culture was hailing me.... I had rationalized the world and the world had rejected me on the basis of color prejudice. ... Out of the necessities of my struggle I had chosen the method of regression, ... here I am at home; I am made of the irrational;

I wade in the irrational. Up to the neck in the irrational

Skin 123).

(Black

Eulalie gives herself all the possible justifications that affirm that her choice to Ato is right. However, Eulalie still finds herself somehow attached to America. In one of the scenes in the play, she appears drinking Coca-Cola. In fact, Eulalie is eager to drink a warm Coca-Cola bottle which symbolizes America rather than fresh coconuts which symbolizes Africa. She tells Ato:

[...] After all, I was only feeling a little homesick and I drank it for sentimental reasons. I could have had a much cooler, sweeter and 
more nourishing substitute in coconuts, couldn't I? $(26 ; 2)$

As much as her memories about America may be painful, it still remains her country of birth and the place where generations of her family lived and died. Though she is trying to readjust with her new accommodation in Africa, it is still difficult for her to accept this sudden change of her environment and customs.

Eulalie even resorts to the American stereotypes that are associated with Africa. As an American, she expects Africa to be the land "of the jungle and the wild life". Therefore, she wanders how "I haven't seen a lion yet!" $(24 ; 2)$. Also in the crux of her imaginative dialogue with her mother's spirit, Eulalie panics when she hears the sounds of the African drums. Unaware of what is happening around her, she imagines that what is going on is a kind of "witch-hunting"(25; 2). She simply follows the false image that America has always produced to her American citizens even the black ones. Based on these stereotypes, Eulalie declares that "there is always witch-hunting out here in Africa" $(25 ; 2)$. Ato later explains that these sounds "were only funeral drums" $(26 ; 2)$ which should not arouse her fear. It is natural for Eulalie to feel that kind of stress which shows the gravity of what she is doing. She has simply alienated herself from all that is familiar to her believing that she can easily exchange her culture with another. Therefore, she expects at the beginning that the African drums would be delightful like that of "jazz" or a "sort of Spanish mambo" $(25 ; 2)$. Later, she discovers that their real sound is actually fearful to her. It is true as Ato comments that "you must have a siesta. If you don't, you'll have a nervous breakdown before you've learnt enough to graduate in primitive cultures . . ." $(26 ; 2)$.

Eulalie finds herself within a totally alien society that she knows nothing about. She, for instance, appears to be ignorant about the difference between Africa and the West regarding the marital relationship. From the African point of view, marriage is not a relation that only binds two people. It is a relation that must include the participation of the entire "extended family". In contrast, the western view of marriage is of a relation that does not exceed the married couple themselves. Any violation to this intimacy by a third party is unwelcomed (Okpaku 19). In one of Esi Kom's visits to her 
son's house in the village, Eulalie finds Esi Kom wandering freely in their house. For such extended families, there are no boundaries between members of the same family. As for Eulalie, she comes from an American background that highly respects privacy. Therefore, Eulalie ends up criticizing Esi's actions and asking Ato to draw his mother's attention to respect Eulalie's privacy saying, "Ato, would you care to ask your mother what she wants in our room?" $(31 ; 3)$.

Eulalie's problem is that she has created for herself a dream world that matches her own romantic expectations regardless of reality. Therefore, any situation that disturbs this dream represents for her a crisis and a shock which compel her to reject all that is related to Africa. She suddenly awakens from her dreams to find that she is surrounded by the Africa that racist America always spoke about. This clearly appears when Esi brings Eulalie a gift of living snails to cook for Ato. The happiness and love with which Esi brings her son his favorite meal is met by Eulalie's terror and disgust with these "crawling things!" $(31 ; 3)$.

Esi's gift to Eulalie therefore turns to be a sort of "rubbish" $(32 ; 3)$ which she must throw out of her house. Eulalie could have simply kept them just for her husband without sharing them with him. However, the snails for her are no longer food, as they become a symbol of the African primitivism that she must throw out of her life. She tells Ato, "If you think I am going to sleep with those creatures, then you are kidding yourself" $(32 ; 3)$. Therefore, she immediately compares this African custom of eating snails to the American context to remind her husband of her civilized American identity:

My dear, did you see a single snail crawling on the streets of New York all the time you were in the States? And anyway, seeing snails and eating them are entirely different things! $(32 ; 3)$.

What Eulalie is experiencing can be described in terms of 'culture shock' " which occurs when a "new culture challenges the fundamental assumptions of one's painstakingly acquired culture" (Lundgren 94). What encourages Eulalie to marry Ato and to return to Africa is most importantly that they belong to the same race. The shock 
however, is that commonality in race is not enough, because there is still the barrier of cultural difference which results from her long separation from Africa. This turns Eulalie into a stranger in her original homeland. Returning physically to Africa can never be the answer to the African American problem:

The sociological impulse of the Afro-American for a surrogate or alternative homeland in modern Africa is neither a realistic nor a tenable proposition, given the crucial, though understandable, cultural differences and realities between the two peoples, and the historical value preferences of the Afro-American (Anosike 446).

This feeling of rejection which Eulalie receives from Africa had to be met by a feeling of nostalgia to America. Therefore, she begins to use her Americanism as a weapon that assures her superiority against the people who consider her inferior for being the descendant of slaves. This is ironic as she is now empowered by the same identity that she was trying to disavow. According to Imanuel Geiss:

The distance of Afro-Americans in time and place from Africa gave their ideas of the 'fatherland' a certain tinge of romanticism and idealization,.... When those idealized notions were exposed to the undeveloped realities of Africa, Afro-Americans (if, as was usually the case, they were unprepared psychologically) suffered an emotional shock and either developed a kind of superiority complex vis-à-vis their brothers - in-race, ... (196).

As an Afro-American, the same culture that has humiliated Eulalie and considered her to be sub-human is now her weapon against her own race. This is the irony of the African American who is always swinging between America and Africa. These feelings become more apparent when Eulalie gets in touch with Ato's family.

Eulalie finds herself behaving offensively with Ato's family to overcome the feelings of alienation and rejection that she feels when they are around. This behavior contradicts completely with the feelings of love that she expected to have for Africa and for Ato's people. Thus, she is 
swinging between longing for Africa and hating it at the same time. Eulalie also begins to hate her visits to Ato's village; this is shown in the way "she surveys the courtyard with disgust" $(41 ; 4)$. After delivering her massage that she does not want to be visited by Ato's family in the city, Eulalie begins to influence Ato to stop their visits to his family. She shows her repulsion in one of her visits saying:

What a blasted mess! Well [She shrugs her
shoulders.] I suppose folks must have
their customs. Though if you ask me,
I think there has been enough messing
round for one day. [...] $(41 ; 4)$

This proves Eulalie's own suffocation with the African environment. She is overtly declaring her insult to the African culture. She is also pushing Ato to rebel against it and to live with her as an American rather than an African. Being in this state, Eulalie indulges in heavy drinking in an attempt to forget that her present suffering is out of her own decision to go back home.

Towards the end of the play, Eulalie confesses that after coming to Africa, she has become worse than she was in America. Back in America, Ato used to address her as "Poor Sweetie Pie"(9; Prelude), a description that she used to reject, believing that by going to Africa "I will not be poor again, will I? I'll just be 'Sweetie Pie' "(9; Prelude). It finally appears to Eulalie that she has achieved nothing and that she has not been saved. She has the same feelings of alienation but this time from people that she hoped that they would appreciate her color and think of her as one of them. As a result, Eulalie begins to declare her disbelief in Africa which caused her nothing but further pain and degradation:

[. . . I shall say anything I like. I am right tired. I must always do things to please you and your folks ... What about the sort of things I like? Aren't they gotten any meaning on this rotten land? $(47-48 ; 5)$ 
Eulalie is clearly attacking the Ghanaian traditions which to her are similar to America's racist laws. Both prevent Eulalie from expressing her individuality and force her to act according to stereotypes whether American or African.

Through this experience, Eulalie turns into a ghost, because she cannot find a home for herself neither in America nor in Africa. Her dilemma is that she has tried to escape the racism and discrimination of the American culture. However, when she reconnects with her African roots, she finds herself using her American identity to demean Africa's culture. She begins to treat her African race from the same racist American perspective that she was raised upon. She realizes that she can never eradicate her American self which will always stand as a barrier between her and Africa. This is the curse that every African American suffers from and which is expressed by Fanon:

Without a Negro past, without a Negro future, it was impossible for me to live my Negrohood. Not yet white, no longer wholly black, I was damned (Black skin 138).

The most important confrontation in the play occurs between Ato and Eulalie. In this incident, Aidoo portrays the dialogue between them not as that of a loving married couple, but of two people who are fed up of wearing each other's masks. Eulalie begins to wage her war against the barbarity of the African culture after hearing from Ato what his family were planning to do to cure her alleged barrenness:

[...] Have they appreciation for anything but their own prehistoric existence? More savage than dinosaurs. With their snails and their potions! You afterwards told me, didn't you, that they wanted me to strip before them and have my belly washed? Washed in that filth!

[She laughs mirthlessly.] What did you tell them I was before you picked me, a strip-tease? $[\ldots](47 ; 5)$.

Eulalie has finally realized that going back to Africa was a mistake. She had expectations that were not fulfilled. In America, she used to be 
judged according to her complexion. When she returned to Africa, her American culture became the criteria of judgment by the African community. Fanon declares:

Shame. Shame and self- contempt. Nausea. When people like me, they tell me it is in spite of my color. When they dislike me, they point out that it is not because of my color.... I turn away from these inspectors of the Ark before the Flood and I attach myself to my brothers, Negroes like myself. To my horror, they too reject me. They are almost white (Black Skin 116-117).

Facing these insults, Ato's mask also begins to fall. He has lived in America suppressing the African part inside him so that he would not feel inferior to the Americans. When he returned to Africa, he had to suppress the American part inside him so that he would not be criticized by his family as a traitor to his culture. This state of tension which he has experienced makes him punish the American culture which has contaminated him, making him incapable of facing himself or his people. Therefore, he finds himself exchanging cultural insults with Eulalie telling her to "[s]hut up! How much does the American negro know?". Eulalie on the other hand responds with great pride as an American saying, "Do you compare these bastards, these stupid narrow-minded savages with us? Do you dare ...?" $(48 ; 5)$.

In a violent and final act of humiliation to Eulalie, Ato slaps her on the face. This failure that occurs to this marital relationship is in fact a wake up call that Aidoo sends to both Africans and African Americans. She calls them to take off their fake masks that were created by the enslaver and the colonizer so that they could start a positive dialogue which has firm bases. The ending of the play is left open as the fate of Ato and Eulalie's marriage is unknown. The open end is in fact an invitation for discussing the right way for achieving unity between members of the same race. Through the example that Aidoo gives in her play, it becomes clear that Africans and African Americans can never unite on the bases of culture. This is the mistake that Aidoo's couple falls into. They assume that they can leap over the gap of time and exchange cultures with ease and brotherhood. However, 
they soon discover that by forming their relationship on cultural grounds, they are actually seeking the main device of their separation. Therefore, Fanon declares:

The truth is that the Negro race has been scattered, that it can no longer claim unity.... Against all the arguments I have just cited, I come back to one fact: Wherever he goes, the Negro remains a Negro (Black Skin 173).

\section{Conclusion}

To sum up, the paper has tried to explain the predicament of the African American returnees. African Americans who had an estranged life away from Africa decide to begin their healing process by attaching themselves to their homeland. They expect to be welcomed by the African people and 
culture, but to their surprise they find themselves abandoned by their brothers.

This idea has been discussed through Ama Ata Aidoo's play, The Dilemma of a Ghost. The dilemma in the play's title is expressed through the character of Eulalie Rush, the African American who by her own will decides to marry an African and returns with him to Africa. Eulalie at the beginning believes that being in Africa is the ultimate achievement of her life. Nevertheless, the more Eulalie spends time in Africa, the more she feels like a stranger. Her sense of alienation increases when she is with Ato's family. Whenever she is confronted with their customs and way of life, she finds herself clinging to her American identity and culture. Towards the end of the play, Eulalie faces a dilemma which she cannot solve. She has tried to live in America as an American, yet she was rejected for bearing the seeds of Africa. When she hoped to be accepted by Africa, Africans rejected her for reminding them of their white oppressors.

Ato and Eulalie's marriage itself is shown to be a dilemma as the audiences are left to question the validity of such a relation. By bringing the African American character to Africa, Aidoo helps in revealing this agitated relation between both sides of the African race. Aidoo's revelation to such complications between both sides is not an attempt to encourage their separation. Her portrayal longs for solutions for this collision between members of the same race. 


\section{Notes}

1 The character of Nana symbolizes the Ghanaian traditions. She is the oldest living member in the Odumna clan. She is over eighty and she "totters in supported by her stick" $(12 ; 1)$. In Ghana, elders are highly respected. They are considered to be the bridge that connects them with their ancestors because of their old age. They are always approached by the rest of the family members to offer them guidance in their problems and their advices are usually followed. They are seen as the keepers of tradition and are always strict in pushing people to follow them (Salm and Falola 138).

2 Ancestors are highly appreciated in West Africa. In fact, their role does not end by death as they continue to have a watchful eye over their descendants (Peek and Yankah 2). This concept is reflected upon the following generations who are supposed to act morally to avoid their ancestors' rage and to ask for their help against misfortune and evil spirits (3). In Ghana, there are even special festivals which are "the Adae festivals". Held by the Akan, these festivals celebrate their remarkable ancestors and chiefs who are now dead. This indeed shows the importance of celebrating their past and linking it to the present generations (Kuada and Chachah 83).

\section{Works Cited}

Aidoo, Ama Ata. Two Plays: The Dilemma of a Ghost, Anowa. New York: Longman Publication Group, 1995. Print.

Anosike, Benji J.O. "Africa and Afro-Americans: The Bases for Greater Understanding Solidarity." The Journal of Negro Education. 51. 4 (Autumn 1982): 434-448. JSTOR. Web. 21 July 2012.

Conniff, Michael L. and Thomas J. Davis. Africans in the Americas: A History of Black Diaspora. Caldwell, New Jersey: The Blackburn Press, 1994. Print. 
Du Bois, W.E.B. The Souls of Black Folk. New York: The Modern library, 2003.Print.

Fanon, Frantz. Black Skin, White Masks. Trans. Charles Lam Markmann. New York: Grove Press, 1967.Print.

---. Toward the African Revolution: Political Essays. Trans. Haakon Chevalier. New York: Grove Press, 1988.Print.

---. The Wretched of the Earth. Trans. Constance Farrington. New York: Grove Press, Inc., 1963.Print.

Geiss, Imanuel. "Pan-Africanism." Journal of Contemporary History. Colonialism and Decolonization. 4.1 (1976): 187 - 200. JSTOR. Web. 18 Feb.2012.

Jackson, Jennifer V. and Mary E. Cothran. "Black Verses Black: The Relationships among African, African American, and African Caribbean Persons." Journal of Black Studies. 33.5 (May-2003): 576-604. JSTOR.Web. 29 Dec.2012.

Talk.

James, Adeola ed. In Their Own Voices: African Women Writers

London, Heinemann, Portsmouth (N.H.) James Currey Ltd., 1990. Print.

Kuada, John and Yao Chachah. Ghana: Understanding the People and their Culture. Accra: Woeli Publishing Services, 1999. Print.

Lundgren, Nancy. Watch and Pray: A Portrait of Fante Village Life in Transition. Fort Worth, Philadelphia: Harcourt College Publishers, Inc., 2002.Print.

Okpaku, Joseph ed. New African Literature and the Arts. Vol. 1. New York: Thomas Y. Crowell Company, 1970. Print.

Peek, Philip M. and Kwesi Yankah, eds. African Folklore: An Encyclopedia. New York, London: Routledge, 2004. Print. 
Salm, Steven J. and Toyin Falola. Culture and Customs of Ghana.

Westport, Connecticut, London: Greenwood Press, 2002. Print.

\section{مستخلص الفنا \\ تباين الحضارات عند العودة للوطن فـي "محنة الثــبح" لأمـا أتا أبياو}

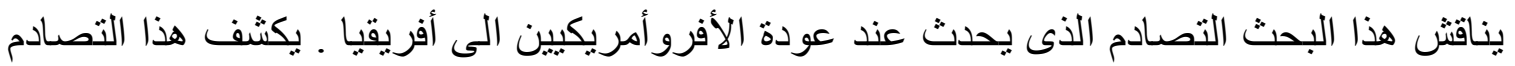

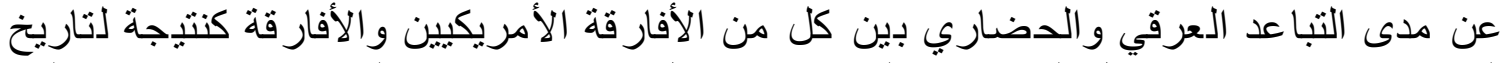

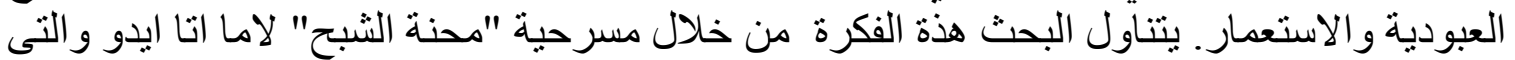

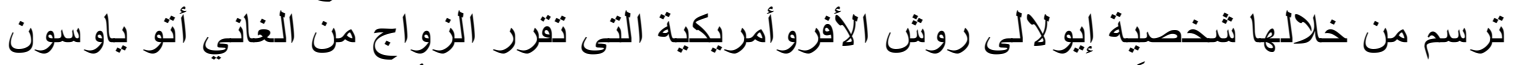

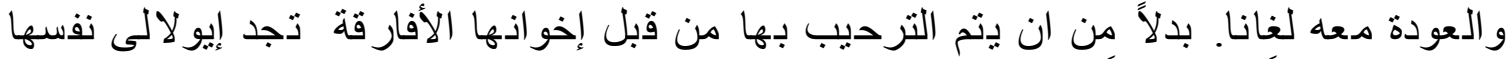

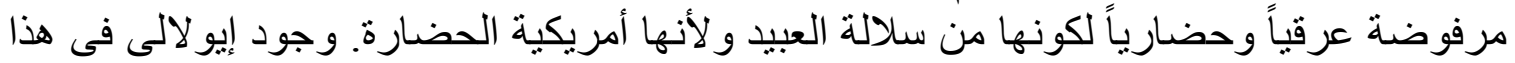

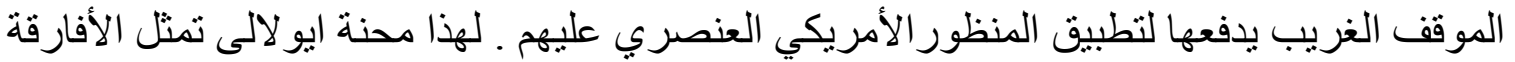

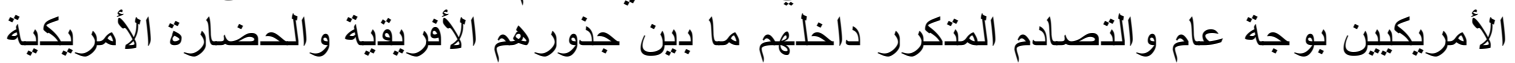

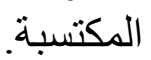


العدد الساد عشر لسنة 2015 ـــ الزَء الثالث 